A-rkivoc

Free to Authors and Readers

\section{A Platinum Open Access Journal}

for Organic Chemistry

Paper

DOAJ Seal

Arkivoc 2021, part iv, 230-240

\title{
Studies in glycopeptide synthesis
}

\author{
Yasuhiro Kajihara, ${ }^{a, b *}$ Rie Nishikawa, ${ }^{a}$ Yuta Maki, a,b and Ryo Okamoto ${ }^{a, b}$ \\ ${ }^{a}$ Department of Chemistry ${ }^{1}$ and Project Research Center for Fundamental Sciences ${ }^{2}$ \\ ${ }^{b}$ Graduate School of Science, Osaka University, 1-1, Machikaneyama, Toyonaka, 560-0043 Japan \\ E-mail: kajihara@chem.sci.osaka-u.ac.jp
}

This article is dedicated to Professor Horst Kunz on the occasion of his 80th birthday

Received 09-30-2020

Accepted 12-03-2020

Published on line 12-11-2020

\section{Abstract}

This short report describes the preliminary results of the synthesis of glycopeptides bearing complex type biantennary sialylglycans. Using the latest efficient auxiliary for peptide-peptide coupling reactions, we successfully synthesized glycopeptides.

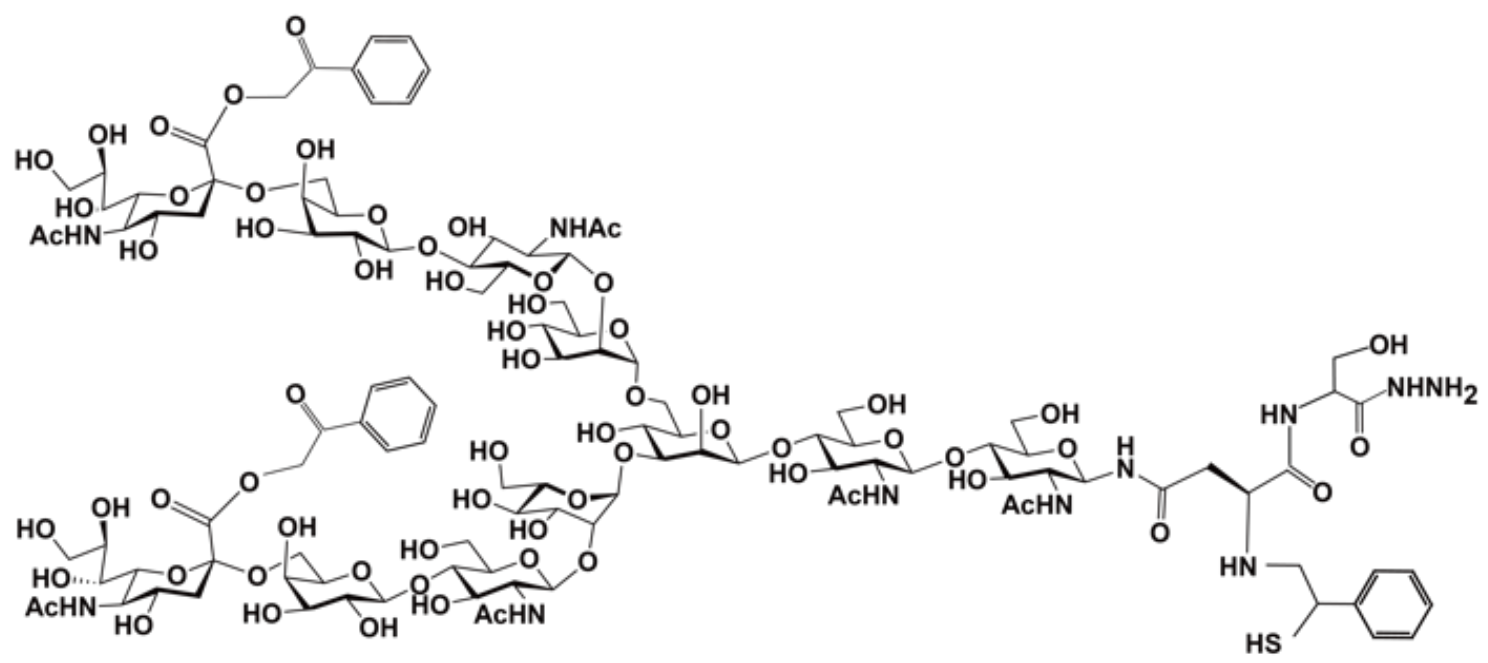

Keywords: Glycopeptide, oligosaccharide, sialic acid, solid phase peptide 


\section{Introduction}

Carbohydrates and their oligomers, glycans, play important roles in many biological events such as cell-cell interactions, immune system regulation, and protein activity stabilization. ${ }^{1}$

Glycans are roughly divided into three groups, as glycoproteins, glycolipids, and glucosaminoglycans. Glycoproteins have asparagine-linked N-glycans and threonine- or serine-linked O-glycans. ${ }^{2}$ The $\mathrm{N}$-linked glycans are further divided into three subgroups such as complex type, high-mannose type, and hybrid type. The biosynthesis of glycoproteins begins in the endoplasmic reticulum, where high-mannose type glycans are attached to the proteins. Depending on their maturation processes in the second organelle (Golgi apparatus), high-mannose type glycans are converted into complex type sialylglycans. Hybrid type glycans possess parts of both the high-mannose type and complex-type in a glycan structure.

However, glycan sequences made in the biosynthetic pathway are not regulated by the gene. Enzymes such as glycosyltransferases and glycosidases regulate the construction of glycan structures. However, the enzymatic regulation results in considerable heterogeneity in the glycan structure. ${ }^{3,4}$ Therefore, glycans on the cell surface and in body fluid show considerable structural diversity, and therefore, we could not identify which glycans are essential for the individual biological events.

In addition to this, a small amount of homogeneous glycans can be isolated from a natural source, but this amount is not enough for extensive investigation of glycobiology. As a result, the study of glycan functions has been hindered.

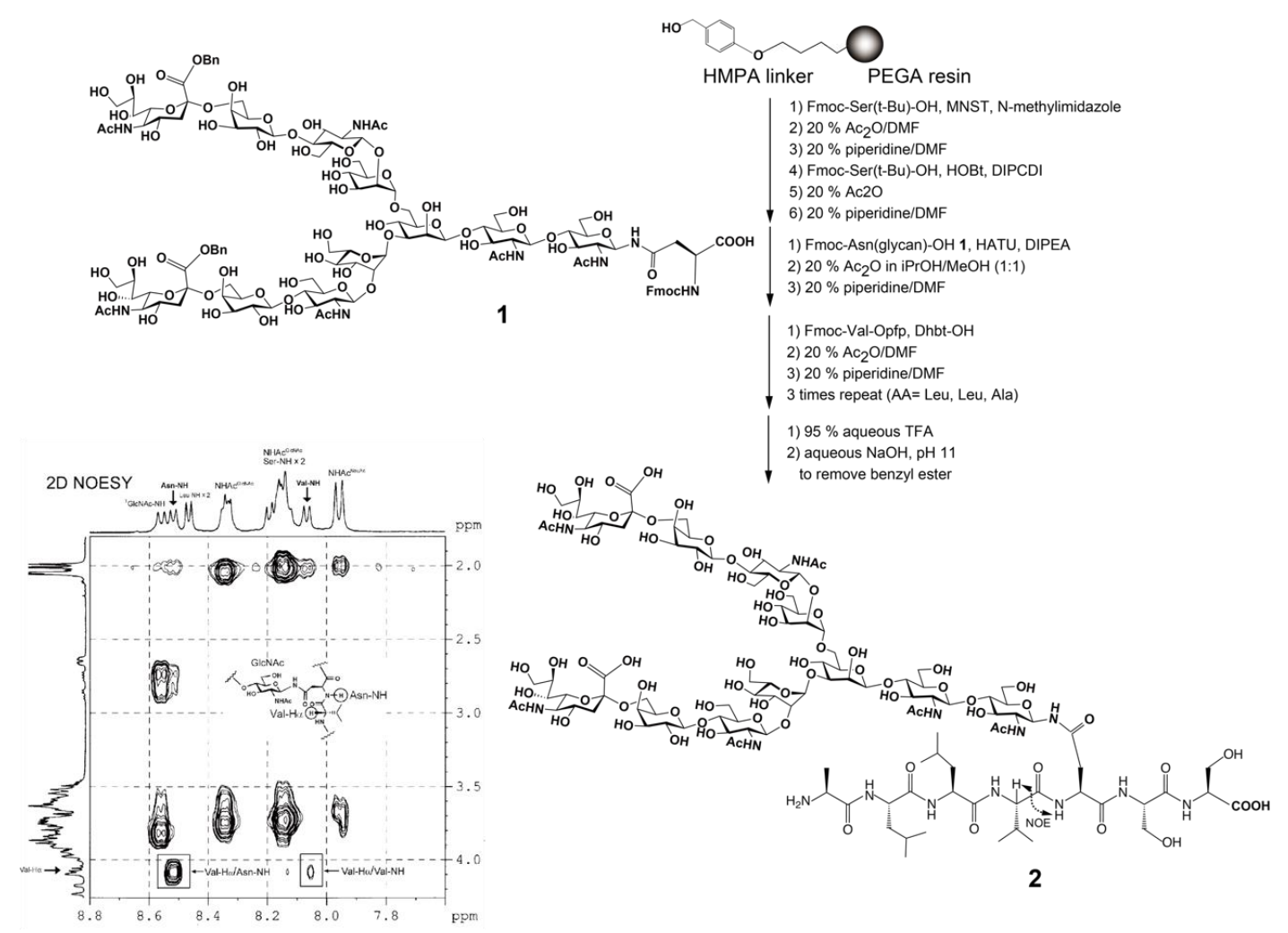

Figure 1. Synthesis of sialylglycopeptide by solid phase peptide synthesis (SPPS). Fmoc-amino acids were used for the conventional SPPS method. Fmoc: fluorenylmethoxycarbonyl; PEGA: poly(ethylene glycol)poly(dimethylacrylamide) copolymer; HMPA linker: hydroxymethylphenoxyacetic acid; MNST: 1(mesitylenesulfonyl)-3-nitro-1,2,4-triazole; HATU: 2-(1H-9-azobenzotriazole-1-yl)-1,1,3,3-tetramethyluronium hexafluorophosphonate; Opfp: pentafluorophenol. 
In order to solve these problems, many groups have developed the chemical or enzymatic synthesis of glycans and glycoconjugates. ${ }^{5-13}$ In particular, the Kunz group has extensively studied the synthesis of glycopeptides over a long period of time. ${ }^{14}$ They efficiently synthesized Fmoc-protected sugar amino acid for solid phase glycopeptide synthesis ${ }^{15}$ and studied protecting group such as allyloxycarbonyl group ${ }^{16}$ and 3-(3pyridyl)allyloxycarbonyl group. ${ }^{17}$ Furthermore, they developed a special linker, Hycron linker, which detaches glycopeptides from resins under the neutral conditions. ${ }^{18}$ This efficient system yielded acid-labile glycopeptides.

Our group has also studied glycopeptide synthesis (Figure 1). However, the synthesis of oligosaccharides was difficult for us to provide a suitable amount for SPPS and therefore our group employed a semi-synthetic method of $\mathrm{N}$-glycans. Fortunately, we isolated a homogeneous complex type biantennary $\mathrm{N}$-linked sialylglycan from egg yolk. ${ }^{19}$ After peptidase digestion, asparagine was protected with an Fmoc group, and two carboxylic acids of sialic acids were efficiently protected with benzyl esters to give Fmoc-Asn-(glycan)-OH 1. We then used 1 for glycopeptide synthesis (Figure 1). ${ }^{20}$ We performed SPPS toward PEGA resin having acidlabile linker and then added Fmoc-Asn-(glycan)-OH 1. After glycopeptide synthesis was complete, the target glycopeptide $\mathbf{2}$ was detached from the resins by acid-cleavage. We found that the sialic acid groups were stable even under strongly acidic conditions due to the benzylesterification. However, this SPPS method has a drawback. Since we could not use an excess amount of the valuable Fmoc-Asn-(glycan)-OH 1, the total synthetic yield from coupling the first amino acid to the resin was not high. In addition to low yields, aspartimide derivative was formed from Fmoc-Asn-(glycan)-OH 1 during the glycopeptide coupling. ${ }^{21}$ Despite, these disadvantages, we did manage to use this method for practical glycopeptide syntheses. Based on a highly supportive and inspiring discussion with Prof. Kunz at a scientific conference, we began work that could finally be published. ${ }^{20}$

In the past decade, glycopeptide syntheses has dramatically improved ${ }^{2,22}$ and recently, glycopeptide syntheses are used for glycoprotein syntheses. ${ }^{22}$ These researches use efficient peptide-peptide coupling reactions. Peptide-peptide coupling is an essential reaction and native chemical ligation (NCL) has been used for the synthesis of proteins. ${ }^{23}$ However NCL requires cysteine residue at the NCL site. Therefore, supplementary methods have been used to provide cysteine surrogates, such as $\beta$-mercaptoamino acids and auxiliary systems. ${ }^{24}$

Under these circumstances, Prof Seitz group developed an excellent auxiliary for peptide-peptide coupling reactions (Figure 2). ${ }^{25,26}$ We had an interest in whether his robust auxiliary could couple bulky Asn-(glycan)-OH and peptide. This short paper reports the preliminary results of this new reaction.

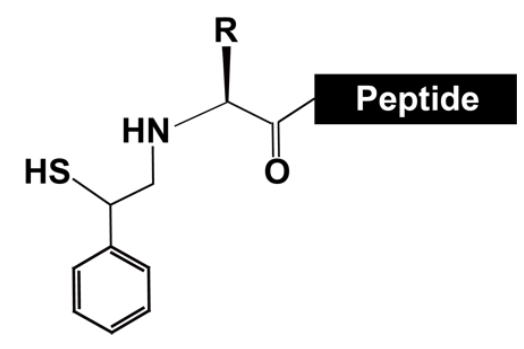

Figure 2. New auxiliary for peptide-peptide coupling. 


\section{Results and Discussion}

\section{Synthesis of auxiliary}

The Seitz group reported a very efficient auxiliary for peptide coupling. ${ }^{25,26}$ Therefore, we examined the same auxiliary for glycopeptide synthesis. This aromatic auxiliary bears a thiol instead of a cysteine to assist NCL, but this auxiliary can be removed from peptides via radical reactions. The Seitz group extensively studied the mechanism of the auxiliary detaching from the peptides after NCL-type reactions.<smiles>OCC(O)c1ccccc1</smiles>

3<smiles>CCOCC(c1ccccc1)C(C)(C)C</smiles>

5

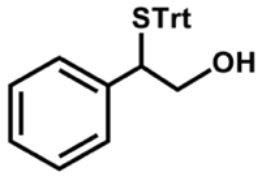

7

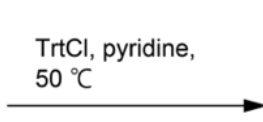

$\mathrm{NH}_{2} \mathrm{NH}_{2} \cdot \mathrm{H}_{2} \mathrm{O}$ $\mathrm{MeOH}$, r.t.

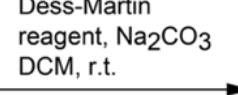
DCM, r.t.<smiles>CCOCC(O)c1ccccc1</smiles>

4

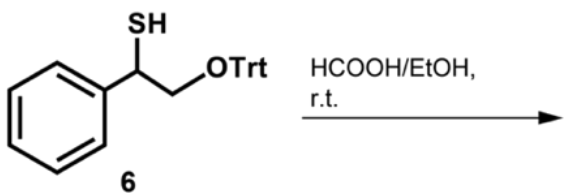<smiles>C[Se]C(C=O)c1ccccc1</smiles>

$0{ }^{\circ} \mathrm{C}$

2) KSAc, DMF,

$40^{\circ} \mathrm{C}$

8
1) $\mathrm{MsCl}$, DIEA, DCM,
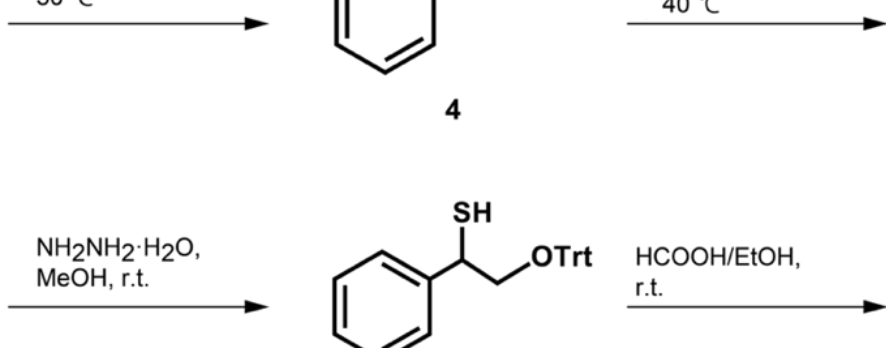

Figure 3. Synthesis of 2-mercapto-2-phenethyl auxiliary 8 from 1-phenylethane-1,2-diol 3. TrtCl: Trityl chloride; $\mathrm{MsCl}$ : methansulfonyl chloride; DIEA: diisopropylethylamine.

However, as the starting material for the synthesis of Seitz's auxiliary was difficult to obtain in Japan, we studied an alternative synthetic route that uses commercially available substrate $\mathbf{3}$ (Figure 3). Trityl protection toward the primary alcohol of 3 gave 4 in 92\% yield. Then, mesylation and substitution with thioacetate yielded compound $\mathbf{5}$ in $72 \%$ yield ( 2 steps). After the acetate group was removed (yield $=84 \%$ ), we found that the trityl group of $\mathbf{6}$ could migrate to the thiol group under acidic conditions, which successfully yielded primary alcohol $\mathbf{7}$ in 78\% yield. Finally, Dess-Martin oxidation yielded the desired auxiliary substrate 8 in $70 \%$ yield.

\section{Preparation of Asn-(complex type sialyl glycan)-OH}

Because we could prepare the Seitz's auxiliary, next we examined the modification of Asn-glycan $9^{20}$ with the auxiliary (Figure 4). For the modification, we explored various reductive-amination conditions and found that picoline borane conditions were more efficient than $\mathrm{NaBH}_{3} \mathrm{CN}$ conditions, because glycan dissolves in water, but not in organic solvent. Toward an amino group of Asn-(glycan)-OH 9, we added auxiliary under the reductive amination condition. Extensive optimizations enabled us to obtain the target $\mathbf{1 0}$ in moderate yield (55\%).

In order to perform peptide-coupling reaction at the $\mathrm{C}$ terminal of $\mathrm{Asn}$-(glycan)-OH, we examined selective esterification of two sialic acids. We had already established the selective benzyl esterification of sialic acid, ${ }^{20}$ 
therefore we employed the same conditions using $\mathrm{Cs}_{2} \mathrm{CO}_{3}$ and subsequent phenacyl (Pac) esterification. ${ }^{27}$ This condition successfully yielded the Phenacyl-esterified TrtS-Aux-Asn-(glycan-Pac)-OH 11 (44\%). This product was characterized by ${ }^{1} \mathrm{H},{ }^{13} \mathrm{C}$, and HSQC NMR analyses (supporting information).

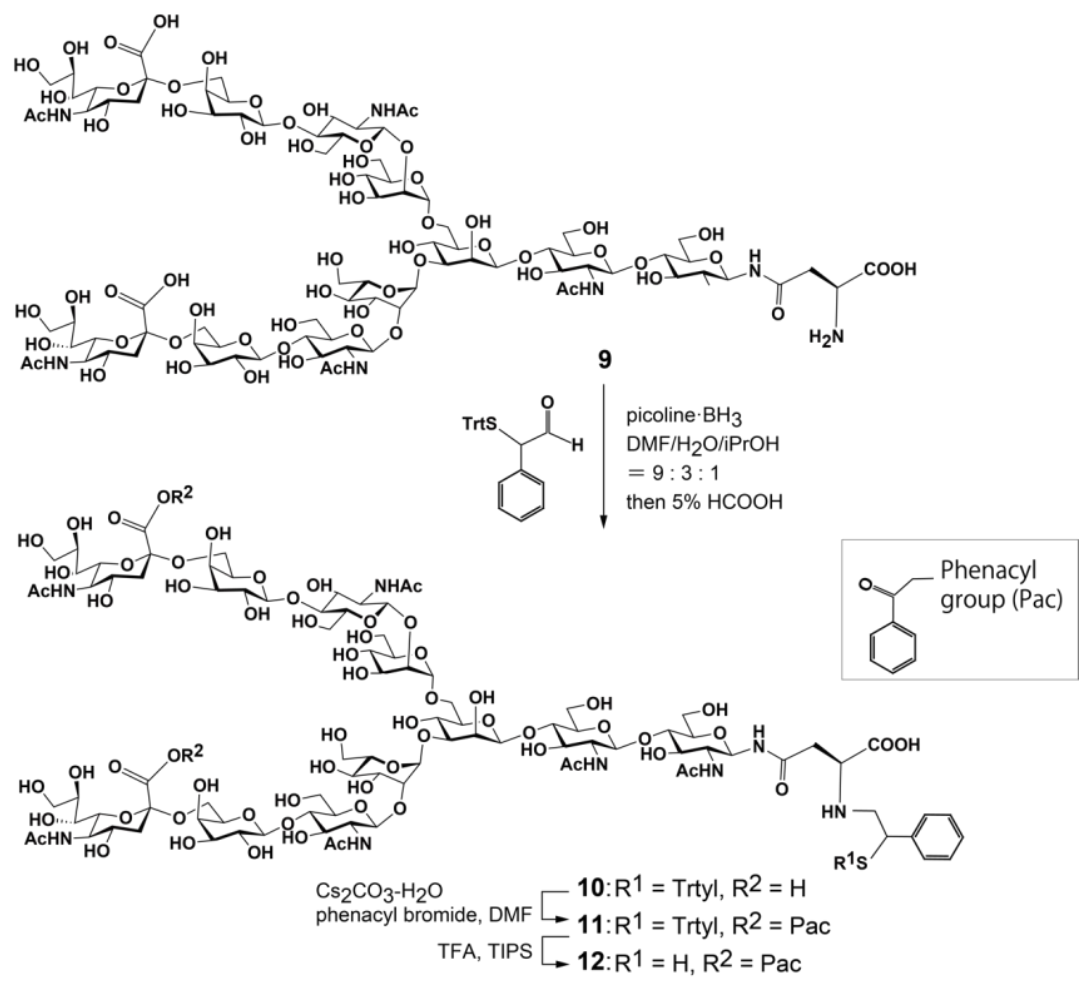

Figure 4. Synthesis of complex type biantennary sialyloligosaccharide bearing the auxiliary.

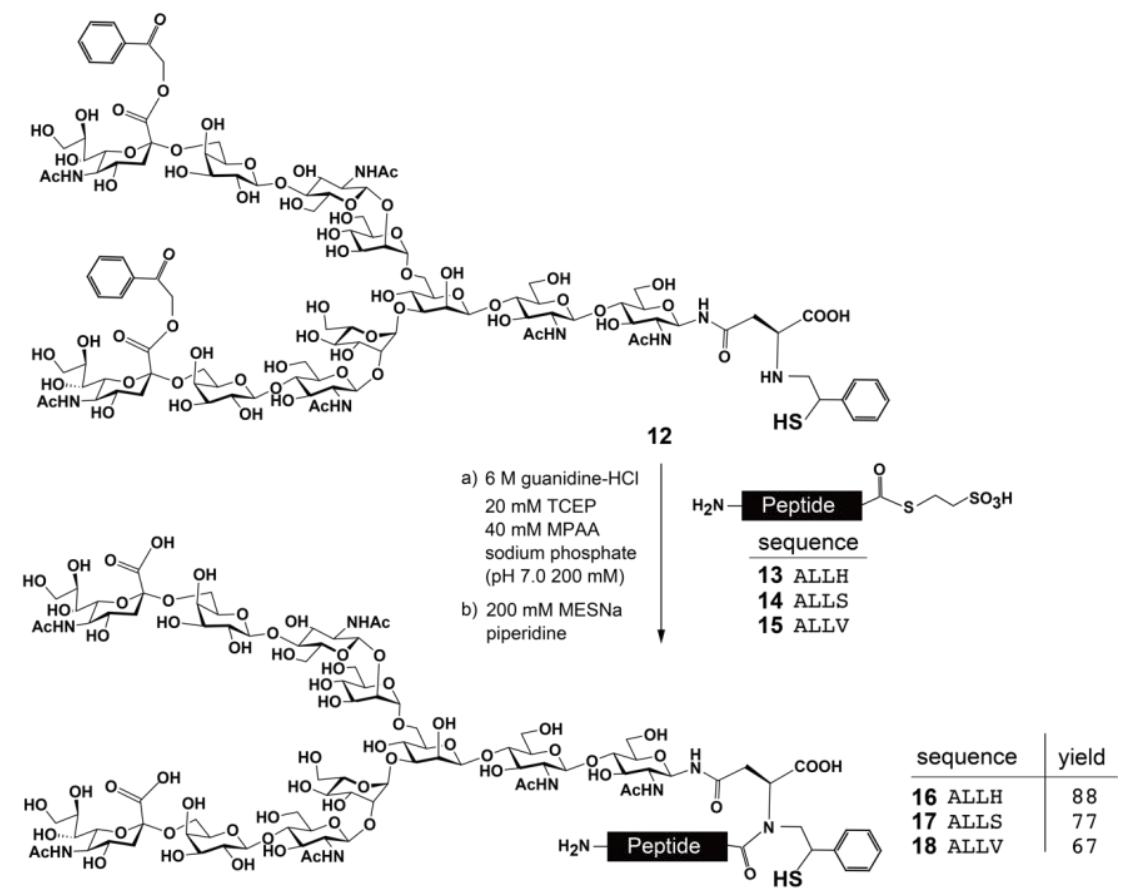

Figure 5. Peptide ligations with auxiliary system. TCEP: triscarboxyethylphosphine; MPAA: 4mercaptophenylacetic acid; MESNa: sodium 2-mercaptoethanesulfonate. 
We next examined peptide ligations between model peptides and auxiliary-bearing Asn-(glycan)-OH 11 (Figure 5). The trityl group of the auxiliary could be removed by trifluoroacetic acid/triisopropylsilane (TFA/TIPS) to yield 12. All peptide coupling reactions employed conventional NCL conditions. ${ }^{23}$ We prepared short three model peptide-thioesters 13-15 by the safe Boc-SPPS. ${ }^{27}$ These model experiments efficiently yielded ligation products 16-18, which were monitored by reverse phase HPLC. These results proved that Seitz's auxiliary works well for glycopeptide synthesis.

The next step of our glycopeptide synthesis was the coupling reaction of another peptide at the C-terminal of TrtS-auxiliary-Asn-(glycan-Pac)-amino acid 11. We first attempted to couple peptide-Asn-(glycan-Pac)-SR, a glycopeptide-thioester, with another peptide. However, peptide-Asn-(glycan-Pac)-SR formed aspartimide 20 before the coupling reaction could proceed. We could not optimize this reaction to avoid the aspartimide formation; therefore, we studied direct coupling with amino acid-hydrazide 19 as a model compound. We employed low-temperature conditions to avoid unexpected asparagine epimerization and aspartimide formation. This direct coupling was already demonstrated by the Unverzagt group. ${ }^{28}$ We confirmed that this direct coupling reaction could yield the desired TrtS-auxiliary-Asn-(glycan-Pac)-amino acid-NHNHBoc 21. Here, we used a mono amino acid hydrazide, but we confirmed that long peptide-hydrazides could be coupled at the C-terminal of Fmoc-Asn-(glycan)-OH.

Finally, we confirmed that the trityl group of the auxiliary, as well as the $t$-Bu and $t$-Boc groups, were removed by TFA/TIPS or TFA/ $\mathrm{H}_{2} \mathrm{O}$ conditions to give the corresponding product 22 in moderate yield. As the Seitz group already demonstrated the detachment of the auxiliary by radical reactions, our data indicates that Seitz's auxiliary can be used for glycopeptide synthesis as well.

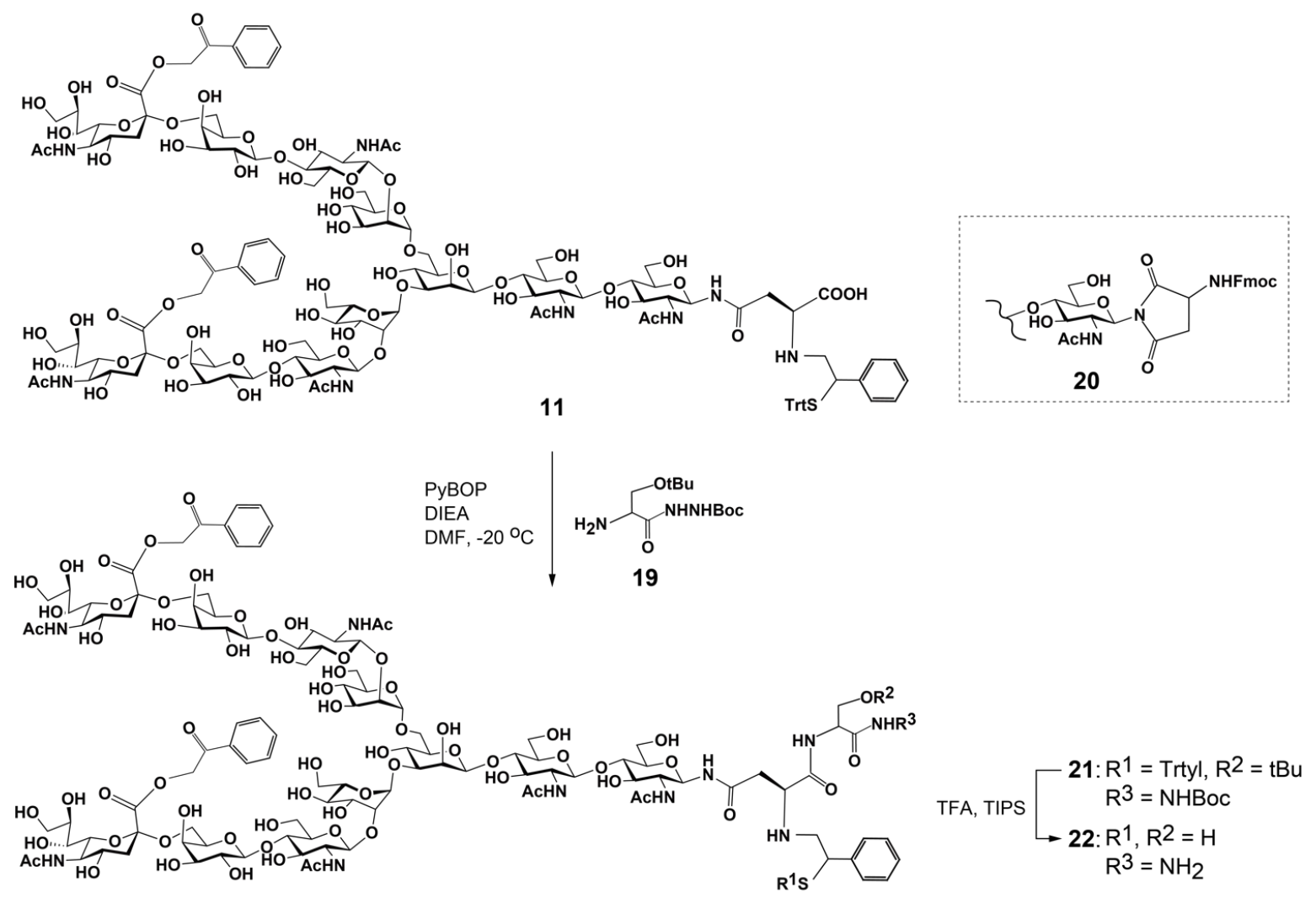

Figure 6. Synthesis of Aux-Asn-(glycan)CONHNH 2. PyBOP: benzotriazole-1-yl-oxy-tris-pyrrolidino-phosphonium hexafluorophosphate; TFA: trifluoroacetic acid; TIPS: triisopropylsilane. 


\section{Conclusions}

We investigated auxiliary-based glycopeptide synthesis using Seitz's auxiliary for efficient peptide coupling. We are currently optimizing the conditions for this method to be used for practical glycopeptide syntheses.

\section{Experimental Section}

General. ${ }^{1} \mathrm{H}$ and ${ }^{13} \mathrm{C}$ NMR spectra were recorded on a $400 \mathrm{MHz}$ spectrometer (Bruker Avance $\mathrm{III}$ ). All ${ }^{1} \mathrm{H}$ chemical shifts are reported in parts per million $(\mathrm{ppm})$ relative to $\mathrm{D}_{2} \mathrm{O}(4.79 \mathrm{ppm})$. Mass spectra were recorded on a Bruker Esquire $3000^{\text {plus }}$, or an amaZon ETD mass spectrometer.

Compound 4. 1-Phenylethane-1,2-diol 3 (3.96g, $28.9 \mathrm{mmol})$, trityl chloride $(8.77 \mathrm{~g}, 31.8 \mathrm{mmol})$ and DMAP (354 $\mathrm{mg}, 2.89 \mathrm{mmol}$ ) were stirred in pyridine $(72 \mathrm{~mL})$ at $50{ }^{\circ} \mathrm{C}$. After the completion of reaction, the mixture was evaporated and the resultant syrupy residue was dissolved into EtOAc and the organic phase was washed with brine and then water. After concentration of organic phase, purification of the residue on a silica gel column (Hex: EtOAc=11:1) gave product $4(10.1 \mathrm{~g}, 92 \%)$. ESI mass calcd. for $\mathrm{C}_{27} \mathrm{H}_{24} \mathrm{O}_{2}[\mathrm{M}+\mathrm{Na}]^{+} 403.2$ Found. $403.3 ;{ }^{1} \mathrm{H}$ $\mathrm{NMR}\left(\mathrm{CDCl}_{3}, 400 \mathrm{MHz}\right) \delta: 7.43-7.14(\mathrm{~m}, 2 \mathrm{H}), 4.71(\mathrm{~m}, 1 \mathrm{H}), 3.33(\mathrm{dd}, 1 \mathrm{H}, 4.1,9.8 \mathrm{~Hz}), 3,29(\mathrm{dd}, 1 \mathrm{H}, 9.36,9.8 \mathrm{~Hz})$, $2.89(\mathrm{bd}, 1 \mathrm{H})$.

Compound 5. To a solution of compound $4(7.11 \mathrm{~g}, 18.7 \mathrm{mmol})$ dissolved in DCM $(95 \mathrm{~mL})$ was added disopropylethylamine $(6.5 \mathrm{~mL}, 37.4 \mathrm{mmol})$ and then methanesulfonyl chloride $(1.75 \mathrm{~mL}, 22.4 \mathrm{mmol})$ at $0{ }^{\circ} \mathrm{C}$. The mixture was stirred at room temperature for $5 \mathrm{~min}$. The reaction mixture was diluted with DCM and organic phase was washed with brine and water. Organic phase was dried over $\mathrm{MgSO}_{4}$ and then concentrated in vacuo. The residue was dried up in vacuo for $1 \mathrm{~h}$ and then the residue was dissolved into DMF (250 $\mathrm{mL})$. To this mixture was added KSAc $(4.27 \mathrm{~g}, 37.4 \mathrm{mmol})$ and then the mixture was stirred at $40{ }^{\circ} \mathrm{C}$. After the reaction completed, the mixture was diluted with EtOAc and the organic phase was washed with brine and then water. The organic phase was dried over $\mathrm{MgSO}_{4}$ and then concentrated in vacuo. Purification of the residue on a silica gel column (Hex: EtOAc=1:1) gave product 5 (5.82 g, 71\%). ESI mass calcd. for $\mathrm{C}_{29} \mathrm{H}_{26} \mathrm{O}_{2} \mathrm{~S}[\mathrm{M}+\mathrm{Na}]^{+} 461.2$ Found. 461.3, ${ }^{1} \mathrm{H}$ NMR $\left(\mathrm{CDCl}_{3}, 400 \mathrm{MHz}\right) \delta: 7.37-7.15(\mathrm{~m}, 2 \mathrm{H}), 4.85(\mathrm{dd}, 1 \mathrm{H}, 6.1,6.1 \mathrm{~Hz}), 3.45(\mathrm{~d}, 1 \mathrm{H}), 3,41$ $(\mathrm{d}, 1 \mathrm{H}), 2.30(\mathrm{~S}, 3 \mathrm{H})$.

Compound 6. To a solution (MeOH:EtOAc $=4: 1,118 \mathrm{~mL}$ ) including compound $5(5.19 \mathrm{~g}, 11.9 \mathrm{mmol}$ ) was slowly added hydrazine- $\mathrm{H}_{2} \mathrm{O}(0.87 \mathrm{~mL}, 17.9 \mathrm{mmol})$ and then the mixture was stirred at room temperature. After $1 \mathrm{~h}$, the solution was diluted with EtOAc and the organic phase was washed with brine and water. The organic phase was dried over $\mathrm{MgSO}_{4}$ and then concentrated in vacuo. Purification of the residue on a silica gel column (Hex: EtOAc=3:1) gave product 6 (3.98 g, 84\%). ESI mass calcd. for $\mathrm{C}_{27} \mathrm{H}_{24} \mathrm{OS}$ [M+Na] ${ }^{+}$Cal. 419.2 Found. 419.4, ${ }^{1} \mathrm{H}$ NMR $\left(\mathrm{CDCl}_{3}, 400 \mathrm{MHz}\right) \delta: 7.40-7.14(\mathrm{~m}, 2 \mathrm{H}), 4.10$ (ddd,1H, 5.1, 6.7, $\left.6.7 \mathrm{~Hz}\right), 3.48$ (dd, 1H, 6.3, 9.4 Hz), 3.42 (dd, $1 \mathrm{H}, 7.4,9.4 \mathrm{~Hz}), 2.20(\mathrm{~d}, 1 \mathrm{H}, 5.1 \mathrm{~Hz})$.

Compound 7. Compound $6(3.58 \mathrm{~g}, 9.03 \mathrm{mmol})$ was dissolved into a solution ( $\left.\mathrm{HCOOH}: \mathrm{Et}_{2} \mathrm{O}=1: 1,30.0 \mathrm{~mL}\right) \mathrm{and}$ then the mixture was stirred at room temperature. After $30 \mathrm{~min}$, piperidine (ca $50 \mathrm{~mL}$ ) was slowly added to the solution at $0{ }^{\circ} \mathrm{C}$. The solution was diluted with EtOAC and the organic phase was washed with sodium bicarbonate solution, brine and water. The organic phase was dried over $\mathrm{MgSO}_{4}$ and then concentrated in vacuo. Purification of the residue on a silica gel column (Hex: EtOAc=6:1) gave product 7 (2.80 g, 78\%). ESI 
mass calcd. for $\mathrm{C}_{27} \mathrm{H}_{24} \mathrm{OS}[\mathrm{M}+\mathrm{Na}]^{+} 419.2$ Found. 419.3, ${ }^{1} \mathrm{H} \mathrm{NMR}\left(\mathrm{CDCl}_{3}, 400 \mathrm{MHz}\right) \delta: 7.44-7.01(\mathrm{~m}), 3.46$ (m,1H), 3.38 (dd,1H, 5.8, 7.6 Hz), $3.29(\mathrm{~m}, 1 \mathrm{H}), 1.50(\mathrm{t}, 1 \mathrm{H}, 6.6 \mathrm{~Hz})$.

Compound 8. To a solution of $\operatorname{DCM}(50.0 \mathrm{~mL})$ including compound 7 (1.94 g, $4.91 \mathrm{mmol})$ and sodium bicarbonate $(29 \mathrm{mmol})$ was dropwisely added a solution of DCM (48 $\mathrm{mL}$ ) including Dess-Martin periodinane $(2.29 \mathrm{~g}, 5.40 \mathrm{mmol})$. The mixture was stirred at room temperature. After $10 \mathrm{~min}$ the organic phase was dilute with $\mathrm{Et}_{2} \mathrm{O}$ and then the organic phase was washed with sodium bicarbonate solution, brine and water. The organic phase was dried over $\mathrm{MgSO}_{4}$ and then concentrated in vacuo. Purification of the residue on a silica gel column (Hex: EtOAc=1:3) gave product 8 (1.35 g, 70\%). ESI mass calcd. for $\mathrm{C}_{27} \mathrm{H}_{22} \mathrm{OS}[\mathrm{M}+\mathrm{Na}]^{+} 417.1$ Found. 417.2; $[\mathrm{M}+\mathrm{K}]^{+} 433.2$ Found. 433.3, ${ }^{1} \mathrm{H} \mathrm{NMR}\left(\mathrm{CDCl}_{3}, 400 \mathrm{MHz}\right) \delta: 9.00(\mathrm{~d}, 1 \mathrm{H}, 3.4 \mathrm{~Hz}), 7.44-7.21(20 \mathrm{H}, \mathrm{m}), 3.99$ $(\mathrm{d}, 1 \mathrm{H}, 3.4 \mathrm{~Hz})$.

Compound 10. Complex type biantennary disialyloligosaccharide 9 (51.4 mg, $21.4 \mu \mathrm{mol}$ ) was dissolved into water $(0.6 \mathrm{~mL})$. To this solution was added a solution of DMF $(1.8 \mathrm{~mL})$-iPrOH $(0.2 \mathrm{~mL})$ containing compound 8 (124 $\mathrm{mg}, 321 \mu \mathrm{mol})$ and then $\mathrm{HCOOH}(0.13 \mathrm{~mL})$ was added to this mixture. Next, to this mixture was added picoline-borane $(36.1 \mathrm{mg}, 0.321 \mathrm{mmol})$ was added and then the mixture was stirred at $30{ }^{\circ} \mathrm{C}$. After $22 \mathrm{~h}$, the product was directly purified on a gel permeation column (Sephadex LH-20, $\mathrm{H}_{2} \mathrm{O}: \mathrm{MeCN}=1: 1$ ) and the fractions containing product were pooled and then lyophilized. Purification of the residue by reverse phase HPLC (C18, $\mathrm{H} 2 \mathrm{O}$ to $60 \% \mathrm{MeCN}$ gradient system) gave product 10 (34.6 mg, 55\%), ESI mass calcd. for $\mathrm{C}_{115} \mathrm{H}_{166} \mathrm{~N}_{8} \mathrm{O}_{64} \mathrm{~S}[\mathrm{M}+\mathrm{H}]$ +2716.0 Found. 2715.8.

Phenacyl-esterification of glycan. A solution $\left(\mathrm{H}_{2} \mathrm{O}, 5.0 \mathrm{~mL}\right)$ containing compound $10(15.1 \mathrm{mg}, 5.56 \mu \mathrm{mol})$ was passed through a short column of Dowex $50 \mathrm{WX} 8\left(\mathrm{H}^{+}\right.$form $)$to make free carboxylic acids and the column was washed with the second portion of water. All eluents were pooled and then was lyophilized. The residue was dissolved into $\mathrm{H}_{2} \mathrm{O}(7.5 \mathrm{~mL})$ and then $\mathrm{pH}$ was adjusted to 4.0 by the addition of a solution of $\mathrm{Cs}_{2} \mathrm{CO}_{3}(50.0$ $\mathrm{mg} / \mathrm{mL}$ ). After lyophilization, the residue was dissolved into DMF $(5.6 \mathrm{~mL})$. To this solution was added phenacyl bromide $(7.7 \mathrm{mg}, 38.9 \mu \mathrm{mol})$ and the mixture was stirred at room temperature for $6 \mathrm{~h}$. The product was directly purified on a gel permeation column (Sephadex LH-20, $\mathrm{H}_{2} \mathrm{O}: \mathrm{MeCN}=1: 1$ ) and the fractions containing product were pooled and then lyophilized. Purification of the residue by reverse phase HPLC (C18, $50 \mathrm{mM} \mathrm{NH}{ }_{4} \mathrm{OAc}$ : MeCN 70:30 to 40: 60 for $60 \mathrm{~min}$ gradient system, $2.5 \mathrm{~mL} / \mathrm{min}$ ) gave product 11 (7.1 mg, 43\%), ESI mass: calcd. for $\mathrm{C}_{131} \mathrm{H}_{178} \mathrm{~N}_{8} \mathrm{O}_{66} \mathrm{~S}[\mathrm{M}+\mathrm{H}]^{+} 2951.1$ Found. 2952.0. ${ }^{1} \mathrm{H}$ NMR $\left(\mathrm{CDCl}_{3}, 400 \mathrm{MHz}\right) \delta: 8.2(\mathrm{~d}$ $2 \mathrm{H}$ ), 7.85, 7.72, 7.54 (each t), 7.5-7.3 (m), 5.82, 5.74 (each $2 \mathrm{H}$, each 16.7 Hz), 5.30, 5.11 (each s, each $1 \mathrm{H}, \mathrm{Man}$ H1), 4.51 (bd, $2 \mathrm{H}$ Gal H-1), 4.35, 4.26, 4.22 (bs, each $1 \mathrm{H}, \mathrm{Man} \mathrm{H} 2$ ), 2.73 (bdd, 2H, NeuAc H3eq), $2.22,2.20$ (s, each $3 \mathrm{H}, \mathrm{Ac}$ ), 2.19, 2.10 (s, each $6 \mathrm{H}, \mathrm{Ac} \times 2$ ), 2.08, 2.07(s, each $3 \mathrm{H}, \mathrm{Ac}$ ).

Ligation experiments by auxiliary group. The peptide-thioesters (mercaptoethanesulfonate ester) 13-15 was prepared by the improved safe-Boc-SPPS method. Removal of trityl group was performed by trifluoroacetic acid and triisopropylsilane (95:5) at room temperature to give 12. After concentration, the product was purified by HPLC reverse phase HPLC (C18, $50 \mathrm{mM} \mathrm{NH}_{4} \mathrm{OAc}$ : MeCN 70:30 to 40: 60 for 60 min gradient system, $2.5 \mathrm{~mL} / \mathrm{min})$. To start the ligation, HS-Asn-(glycan)-OH having an auxiliary $12(2.5 \mathrm{mM})$ was dissolved a solution (200 mM sodium phosphate buffer, $\mathrm{pH} 7.0$ ) containing peptide-thioester (5.0 mM), 6.0 M Guanidine- $\mathrm{HCl}$, and tris(2-carboxyethyl)phosphine (TCEP, $20 \mathrm{mM}$ ) and 4-mercaptofenyl acetic acid (MPAA, $40 \mathrm{mM}$ ). The reaction mixture was incubated at room temperature and the reactions were monitored by HPLC.

In terms of HPLC system, solution-A $(0.1 \% \mathrm{HCCOH})$ and solution-B $(0.09 \% \mathrm{HCOOH}$ in $90 \% \mathrm{MeCN}$ solution) were used for gradient system.

Synthesis of glycopeptide $\mathrm{H}_{2} \mathrm{~N}-\mathrm{ALLH}-A s n(G l y c a n)-\mathrm{OH}$ (16). The reaction was monitored by reverse phase HPLC ( $A: B$ solutions $=80: 20$ to $50: 50$ for $15 \mathrm{~min}, 0.2 \mathrm{~mL} / \mathrm{min}, \mathrm{C}-18$ Proteonavi column, Shiseido Ltd). During the 
reaction, Pac ester was partially deprotected in the presence of MPAA. Therefore coupling yield was estimated after removal of all Pac ester with $200 \mathrm{mM}$ sodium 2-mercaptoethanesulfonate (MESNa) and $0.5 \mu \mathrm{L}$ piperidine. ALLH-Asn(Glycan)-OH was obtained in $88 \%$. ESI mass calcd. for $\mathrm{C}_{117} \mathrm{H}_{186} \mathrm{~N}_{14} \mathrm{O}_{68} \mathrm{~S}[\mathrm{M}+\mathrm{H}]^{+} 2908.1$; Found.2908.2.

Synthesis of glycopeptide, $\mathrm{H}_{\mathbf{2}} \mathbf{N}$-ALLS-Asn(Glycan-Pac)-OH (17). The ligation reaction was performed following the same procedure as in the preparation of $\mathrm{H}_{2} \mathrm{~N}$-ALLH-Asn(Glycan)-OH. During ligation reaction, Pac group was partially removed. The coupling yield was estimated both Pac-protected and deprotected products as total yield (77\%) ESI mass calcd. for $\mathrm{C}_{130} \mathrm{H}_{196} \mathrm{~N}_{12} \mathrm{O}_{71} \mathrm{~S}[\mathrm{M}+\mathrm{H}]^{+}$3094.18; Found.3094.32.

Synthesis of glycopeptide, $\mathrm{H}_{2} \mathbf{N}$-ALLV-Asn(Glycan-Pac)-OH (18). The ligation reaction was performed with the same procedure in the preparation of $\mathrm{H}_{2} \mathrm{~N}-\mathrm{ALLH}-\mathrm{Asn}$ (Glycan)-OH. During ligation reaction, Pac group was partially removed. The coupling yield was estimated both Pac-protected and deprotected products as total yield (67\%). ESI mass calcd. for $\mathrm{C}_{132} \mathrm{H}_{200} \mathrm{~N}_{12} \mathrm{O}_{70} \mathrm{~S}[\mathrm{M}+\mathrm{H}]^{+} 3106.22$ Found.3106.38.

Fmoc-Ser(O-tert-Bu)-NHNHBoc. Commercially available Fmoc-HN-Ser(O-tBu)-OH was converted into $\mathrm{H}_{2} \mathrm{~N}$ Ser(O-tBu)- NHNHBoc by two steps conversion. Fmoc-HN-Ser(O-tBu)-OH (1.22 g, $2.45 \mathrm{mmol})$ was dissolved into DMF $(12.0 \mathrm{~mL})$ and then tert-butyl carbazate $(1.73 \mathrm{~g}, 13.0 \mathrm{mmol})$ and DIC- $\mathrm{HCl}(1.86 \mathrm{~g}, 9.7 \mathrm{mmol})$ were added. The mixture was left at room temperature for $30 \mathrm{~min}$. The mixture was diluted with EtOAc and washed with brine and water and the organic phase was concentrated in vacuo. Purification of the residue on a silica gel (Hex:EtOAC $=1: 1$ ) gave Fmoc-Ser(O-tert-Bu)-NHNHBoc $(1.17 \mathrm{~g}, 90 \%)$. ESI mass calcd. for $\mathrm{C}_{27} \mathrm{H}_{35} \mathrm{~N}_{3} \mathrm{O}_{6}$ $[\mathrm{M}+\mathrm{Na}]^{+} 520.2$ Found. 520.2. ${ }^{1} \mathrm{HNMR}\left(\mathrm{CDCl}_{3}, 400 \mathrm{MHz}\right) \delta: 7.65-7.25(\mathrm{~m}, 10 \mathrm{H}), 5.70(\mathrm{~s}, 1 \mathrm{H}), 4.40(\mathrm{~d}, 2 \mathrm{H}), 4.32$ $(\mathrm{s}, 3 \mathrm{H}), 3.81(\mathrm{~s}, 1 \mathrm{H}), 1.26(\mathrm{~s}, 9 \mathrm{H})$.

$\mathrm{H}_{2} \mathrm{~N}$-Ser(O-tert-Bu)-CONHNHBoc (19). Fmoc-Ser(O-tert-Bu)-CONHNHBoc (1.22 g, $\left.2.45 \mathrm{mmol}\right)$ and piperidine $(2.0 \mathrm{~mL})$ were stirred in DMF $(8.0 \mathrm{~mL})$ at room temperature. The mixture was azeotropically dried with toluene in vacuo. Purification of the residue by reverse phase HPLC (0.1\% TFA: 0.1\%TFA in 90\% MeCN from 80:20 to 50:50 gradient syste for $30 \mathrm{~min}, 2.0 \mathrm{~mL} / \mathrm{min}$, capcellpack column) gave $\mathrm{H}_{2} \mathrm{~N}$-Ser(O-tert-Bu)-CONHNHBoc 17 (390.6 mg, 58\%). ESI mass calcd. for $\mathrm{C}_{12} \mathrm{H}_{25} \mathrm{~N}_{3} \mathrm{O}_{4}[\mathrm{M}+\mathrm{H}]^{+}$276.2, Obsd. 276.1

Coupling of TrtS-auxiliary-Asn-(glycan-Pac)-OH 11 with $\mathrm{H}_{2} \mathbf{N}$-Ser(O-tert-Bu)-CONHNHBoc (19). $\mathrm{H}_{2} \mathrm{~N}$-Ser(O-tertBu)-CONHNHBoc 19 (0.93 mg, $3.39 \mu \mathrm{mol})$ and PyBOP (0.88 mg, $1.70 \mu \mathrm{mol})$ was dissolved into DMF-DMSO (1:1, $68 \mu \mathrm{L}$ ) and to this solution was added Fmoc-Asn(glycan-Pac2)-OH $11(1.0 \mathrm{mg}, 0.34 \mu \mathrm{mol})$. To this solution was added DIEA $(0.41 \mu \mathrm{L}, 2.37 \mu \mathrm{mol})$ and the mixture was stirred at $0{ }^{\circ} \mathrm{C}$. Purification by reverse phase $\mathrm{HPLC}$ (Cadenza M column, Kyoto, A: B solution 75:25 to 5: 95 for $15 \mathrm{~min}, 0.2 \mathrm{~mL} / \mathrm{min}$ ) give product 21 (ca $52 \%$ ). ESI mass calcd. for $\mathrm{C}_{143} \mathrm{H}_{201} \mathrm{~N}_{11} \mathrm{O}_{69} \mathrm{~S}[\mathrm{M}+\mathrm{H}]^{+}$3209.2, Obsd. 3209.3

Synthesis of HS-auxiliary-Asn-(glycan-Pac)-Ser-CONHNH 2 (22). The trityl group, $t$-Bu and Boc group could be removed with TFA:TISP $(95: 5)$ at $0{ }^{\circ} \mathrm{C}$. After completion, the mixture was concentrated in vacuo. HPLC purification gave 22. ESI mass calcd. for $\mathrm{C}_{115} \mathrm{H}_{171} \mathrm{~N}_{11} \mathrm{O}_{67} \mathrm{~S}[\mathrm{M}+\mathrm{H}]^{+}$2811.00, Obsd. 2810.9

\section{Supplementary Material}

${ }^{1} \mathrm{H},{ }^{13} \mathrm{C}$ NMR spectra, Mass data, and HPLC profiles of compounds. 
I sincerely thank Professor Horst Kunz for continuous positive advice and encouragement from our first meeting in 1992 until the present. ${ }^{29}$ This work was supported by Japan Society for the promotion of science (KAKENHI:17H01214).

\section{References}

1. Varki, A. Glycobiology 2017, 27, 3-49. https://doi.org/10.1093/glycob/cww086

2. Unverzagt, C.; Kajihara, Y. Chem. Soc. Rev. 2013, 42, 4408-20. https://doi.org/10.1039/c3cs35485g

3. Pan S.; Chen, R.; Aebersold, R.; Brentnall, T. A. Mol. Cell. Proteomics 2011, 10, R110.003251. https://doi.org/10.1074/mcp.R110.003251

4. Chirino, A. J.; Mire-Sluis, A. Nat. Biotech. 2004, 22, 1383-1391. https://doi.org/10.1038/nbt1030

5. Kulkarni, S. S.; Wang, C. C.; Sabbavarapu, N. M.; Podilapu, A. R.; Liao, P. H.; Hung, S. C., Chem. Rev. 2018, 118, 8025-8104. https://doi.org/10.1021/acs.chemrev.8b00036

6. Panza, M.; Pistorio, S. G.; Stine, K. J.; Demchenko, A. V. Chem. Rev. 2018, 118, 8105-8150. https://doi.org/10.1021/acs.chemrev.8b00051

7. Wen, L.; Edmunds, G.; Gibbons, C.; Zhang, J.; Gadi, M. R.; Zhu, H.; Fang, J.; Liu, X.; Kong, Y.; Wang, P. G., Toward Automated Enzymatic Synthesis of Oligosaccharides. Chem. Rev. 2018, 118, 8151-8187. https://doi.org/10.1021/acs.chemrev.8b00066

8. Palitzsch, B.; Gaidzik, N.; Stergiou, N.; Stahn, S.; Hartmann, S.; Gerlitzki, B.; Teusch, N.; Flemming, P.; Schmitt, E.; Kunz, H. Angew.Chem.Int. Ed. 2016, 55, 2894-2898.

https://doi.org/10.1002/anie.201509935

9. Palitzsch, B.; Hartmann, S.; Stergiou, N.; Glaffig, M.; Schmitt, E.; Kunz, H. Angew. Chem.Int.Ed. 2014, 53, 14245-14249.

https://doi.org/10.1002/anie.201406843

10. Gaidzik, N.; Kaiser, A.; Kowalczyk, D.; Westerlind, U.; Gerlitzki, B.; Sinn, H. P.; Schmitt, E.; Kunz, H. Angew. Chem. Int. Ed. 2011, 50, 9977-9981. https://doi.org/10.1002/anie.201104529

11. Kaiser, A.; Gaidzik, N.; Becker, T.; Menge, C.; Groh, K.; Cai, H.; Li, Y. M.; Gerlitzki, B.; Schmitt, E.; Kunz, H. Angew. Chem. Int. Ed. 2010, 49, 3688-3692.

https://doi.org/10.1002/anie.201000462

12. Westerlind, U.; Schroder, H.; Hobel, A.; Gaidzik, N.; Kaiser, A.; Niemeyer, C. M.; Schmitt, E.; Waldmann, H.; Kunz, H. Angew. Chem. Int. Ed. 2009, 48, 8263-8267.

https://doi.org/10.1002/anie.200902963

13. Kaiser, A.; Gaidzik, N.; Westerlind, U.; Kowalczyk, D.; Hobel, A.; Schmitt, E.; Kunz, H. Angew. Chem. Int. Ed. 2009, 48, 7551-7555. https://doi.org/10.1002/anie.200902564

14. Kunz, H. Angew. Chem. Int. Ed. 1987, 26, 294-308.

https://doi.org/10.1002/anie.198702941

15. Schultheiß-Reimann, P.; Kunz, H. Angew. Chem. 1983, 39-46. https://doi.org/10.1002/anie.198300390 
16. Kunz, H.; Unverzagt, C., Angew. Chem. Int. Ed. 1984, 23, 436-437.

https://doi.org/10.1002/anie.198404361

17. Angew. Chem.Int. Ed. 1990, 29, 1457-1459.

https://doi.org/10.1002/anie.199014571

18. Seitz, O.; Kunz, H. J. Org. Chem. 1997, 62, 813-826.

https://doi.org/10.1021/j0960743w

19. Seko, A.; Koketsu, M.; Nishizono, M.; Enoki, Y.; Ibrahim, H. R.; Juneja, L. R.; Kim, M.; Yamamoto, T., Biochimica et Biophysica Acta (BBA) - General Subjects 1997, 1335, 23-32.

https://doi.org/10.1016/S0304-4165(96)00118-3

20. Yamamoto, N.; Ohmori, Y.; Sakakibara, T.; Sasaki, K.; Juneja, L. R.; Kajihara, Y. Angew. Chem., Int. Ed. 2003, 42, 2537-2540.

https://doi.org/10.1002/anie.200250572

21. Yamamoto, N.; Takayanagi, A.; Yoshino, A.; Sakakibara, T.; Kajihara, Y. Chem. Eur. J. 2007, 13, 613-625. https://doi.org/10.1002/chem.200600179

22. Unverzagt, C.; Kajihara, Y. Opin. Chem. Biol. 2018, 46, 130-137.

https://doi.org/10.1016/j.cbpa.2018.07.004

23. Dawson, P. E.; Muir, T. W.; Clark-Lewis, I.; Kent, S. B. H. Science 1994, 266, 776-779.

https://doi.org/10.1126/science.7973629

24. Burke, H. M.; McSweeney, L.; Scanlan, E. M. Nat. Commun. 2017, 8, 15655.

https://doi.org/10.1038/ncomms15655

25. Loibl, S. F.; Harpaz, Z.; Seitz, O. Angew.Chem. Int. Ed. 2015, 54, 15055-9.

https://doi.org/10.1002/anie.201505274

26. Loibl, S. F.; Dallmann, A.; Hennig, K.; Juds, C.; Seitz, O. Chem. Eur. J. 2018, 24, 3623-3633. DOI.

10.1002/chem.201705927

https://doi.org/10.1002/chem.201705927

27. Murakami, M.; Okamoto, R.; Izumi, M.; Kajihara, Y. Angew. Chem. Int. Ed. 2012, 51, 3567-3572.

https://doi.org/10.1002/anie.201109034

28. Unverzagt, C. Tetrahedron Lett. 1997, 38, 5627-5630.

https://doi.org/10.1016/S0040-4039(97)01278-1

29. The author first met Professor Kunz at an International Carbohydrate Conference in Paris as a graduate student in 1992. He remembers with gratitude and pleasure meetings with Professor Kunz over the last 28 years and thanks him for his encouragement and interest in his work. A visit to Mainz was particularly memorable where he met Mrs. Kunz. The authors have interacted with Professors Unverzagt and Seitz who were the member of the Kunz group.

This paper is an open access article distributed under the terms of the Creative Commons Attribution (CC BY) license (http://creativecommons.org/licenses/by/4.0/) 